\title{
Proses Fraksionasi Biomassa dari Tandan Kosong Kelapa Sawit melalui Metode Organosolv Etanol dengan Penambahan Katalis
}

\author{
Harum Azizah Darojati ${ }^{1 *}$, Ronny Purwadi ${ }^{2}$, Carolus Borromeus Rasrendra ${ }^{2}$ \\ ${ }^{1}$ Sekolah Tinggi Teknologi Nuklir BATAN, Jl. Babarsari PO BOX 6101 ykbb, Yogyakarta, Indonesia \\ ${ }^{2}$ Institut Teknologi Bandung, Jl. Ganesha 10 Bandung, Indonesia
}

Diterima: 15 September 2020, Revisi akhir: 6 November 2020, Disetujui terbit: 30 Desember 2020

\section{Biomass Fractionation Process from Oil Palm Empty Fruit Bunch by Catalyzed Ethanol Organosolv}

\begin{abstract}
Abstrak
Tandan kosong kelapa sawit (TKKS) merupakan salah satu biomassa lignoselulosa dengan komposisi utama terdiri atas selulosa, hemiselulosa, dan lignin. Pemisahan komponen lignoselulosa dapat dilakukan dengan fraksionasi melalui metode organosolv. Penelitian ini bertujuan untuk mendapatkan kondisi operasi dari proses fraksionasi biomassa lignoselulosa TKKS dengan metode organosolv berkatalis $\mathrm{NH}_{4} \mathrm{OH}$. Penelitian dirancang menggunakan Metode Placket-Burman dengan variasi rasio fraksi berat, rasio etanol:air, temperatur, konsentrasi katalis, dan waktu. Hasil penelitian menunjukkan bahwa fraksionasi dapat dilakukan dengan baik pada rasio fraksi berat biomassa $10 \%$, perbandingan etanol:air sebanyak $1: 1$, temperatur $160^{\circ} \mathrm{C}$, dan konsentrasi katalis $5 \% \mathrm{NH}_{4} \mathrm{OH}$, selama 120 menit. Kondisi tersebut dapat menghasilkan perolehan selulosa 98,07\%, perolehan hemiselulosa $98,71 \%$ dan penghilangan lignin 60,28\%. Penggunaan kembali pelarut dilakukan dengan memisahkan lignin melalui presipitasi $\mathrm{H}_{2} \mathrm{SO}_{4} 1 \mathrm{M}$ pada $\mathrm{pH}$ 2. Penggunaan pelarut untuk kedua kali dapat menghasilkan perolehan selulosa $98,03 \%$, perolehan hemiselulosa $65,61 \%$ dan penghilangan lignin $59,81 \%$. Sementara itu, dari perhitungan neraca massa, dapat dilihat bahwa proses tersebut dapat dilakukan karena kehilangan pelarut dan padatan relatif sedikit. Kehilangan padatan berkisar pada 19,06\% dari umpan TKKS, sedangkan pelarut yang dapat diambil adalah sekitar 59,34\% dari umpan etanol.
\end{abstract}

Kata kunci: fraksionasi, katalis, lignoselulosa, organosolv, TKKS

\section{Abstract}

Oil palm empty fruit bunches (OPEFB) is a potential lignocellulosic biomass with main composition are cellulose, hemicellulose, and lignin. This process of OPEFB can be done with fractionation using organosolv method. This study aims to get a configuration of lignocellulosic biomass fractionation process of $\mathrm{NH}_{4} \mathrm{OH}$ catalyzed ethanol organosolv method. This experiment was performed using Placket-Burman method with variation of biomass loading, ratio of ethanol:water, temperature, catalyst concentration, and time. The results showed that fractionation can be done on biomass loading of $10 \%$, at temperature of $160^{\circ} \mathrm{C}$, ratio of ethanol: water 1:1, catalyst concentration of 5\%, for 120 minutes. This condition result in $98.07 \%$ yield of cellulose, $98.71 \%$ yield of hemicellulose, and $60.28 \%$ lignin removal. Reusing solvent was done by lignin precipitation in $1 \mathrm{M}^{\circ} \mathrm{H}_{2} \mathrm{SO}_{4}$ at $\mathrm{pH} 2$. The usage of solvent at second time in the same conditions result in 98.03\% yield of cellulose, $65.61 \%$ yield of hemicellulose and $59.81 \%$ lignin removal. Therefore, from the mass balance of fractionation process, it can be observed that loss of solvent and solid are minor. The solid loss was about 19,08\% of OPEFB feed, while solvent recovery was about 59,34\% from ethanol feed.

Keywords: catalyze, fractionation, lignocellulose, OPEFB, organosolv 


\section{Pendahuluan}

Besarnya produksi minyak sawit di Indonesia menyisakan tandan kosong kelapa sawit (TKKS) yang potensial sebagai sebagai produk samping yang memiliki potensi besar sebagai sumber biomasa lignoselulosa. Data dari Rahmanulloh (2020) menunjukkan bahwa Indonesia dapat menghasilkan minyak sawit mentah atau crude palm oil (CPO) sebanyak 42,5 juta ton, dan produksi tandan buah segar (TBS) di Indonesia mencapai 194,17 juta ton, dengan setiap pengolahan 1 ton TBS (Tandan Buah Segar) dihasilkan Tandan Kosong Kelapa Sawit (TKKS) sebanyak $22-23 \%$ TKKS atau sebanyak $220-$ $230 \mathrm{~kg}$ TKKS (Fuadi and Heri, 2016).

Komponen terbesar penyusun TKKS terdiri atas $45,95 \%$ selulosa, 16,49\% hemiselulosa dan 22,48\% lignin (Wardani, 2014). Menurut Yoo (2012) dan North (2014) setiap komponen tersebut dapat diubah menjadi produk yang lebih bernilai guna dan bernilai jual. Selulosa yang merupakan komponen terbesar, dapat diolah menjadi sumber energi/bahan bakar cair berupa bioetanol, asam organik, pelarut, pelumas dan polimer. Selulosa juga dapat diproses menjadi serat nanoselulosa yang ringan, tetapi kuat, yang dapat dimanfaatkan untuk aplikasi di berbagai bidang seperti bahan nanokomposit, bahan yang dimodifikasi permukaan, dan kertas transparan dengan fungsi khusus (Phantong et al., 2018). Hemiselulosa mengandung xilan yang terdiri atas unit-unit xilosa, dapat diolah menjadi etanol, xilitol (pemanis buatan), resin, dan nylon. Sementara itu, lignin dapat diolah menjadi bahan dasar kimia organik, batu bara dan bahan bakar padat (North, 2014; Yoo, 2012).

Komponen utama lignoselulosa berupa lignin, selulosa dan hemiselulosa dapat ditingkatkan nilai gunanya melalui proses pemisahan yang disebut fraksionasi biomassa. Fraksionasi ini dapat dilakukan dengan menggunakan metode organosolv. Fraksionasi metode organosolv telah banyak dilakukan dan memberikan hasil yang baik, bahkan pada skala pilot (Harmsen et al., 2010). Metode organosolv dilakukan dengan menggunakan pelarut organik dan dapat ditambahkan katalis berupa basa atau asam. Pelarut organik berupa etanol sering digunakan di industri untuk melakukan proses fraksionasi (Akgul dan Kirci, 2009).

Menurut Mesa et al. (2011), basa dapat digunakan sebagai katalis karena dapat membantu masuknya etanol ke struktur material sekaligus mendelignifikasi TKKS. Salah satu basa yang dapat digunakan sebagai katalis adalah $\mathrm{NH}_{4} \mathrm{OH}$, dengan pertimbangan karena senyawa tersebut mampu didaur ulang dengan mudah dan tidak bereaksi dengan etanol (Park et al., 1988).

Fraksionasi yang ideal adalah yang dapat menghasilkan komposisi selulosa, dan hemiselulosa yang besar, serta penghilangan lignin/delignifikasi yang tinggi. Pada fraksionasi lignoselulosa menggunakan organosolv etanol berkatalis, faktor yang paling berpengaruh adalah temperatur, perbandingan etanol:air, waktu, rasio fraksi berat, dan konsentrasi katalis (Wildschut et al., 2013; Lopes et al., 2013; Akgul and Kirci, 2009). Penentuan nilai atau kondisi dari setiap faktor tersebut tidak mudah, sehingga diperlukan suatu penelitian untuk mendapatkan proses fraksionasi terbaik yang meliputi faktor-faktor tersebut.

Meskipun sudah banyak penelitian yang menggunakan metode organosolv, namun masih terdapat beberapa hambatan untuk mengaplikasikannya ke dalam skala industri, terutama hambatan berupa kesulitan mendaur ulang pelarut dan katalis yang menyebabkan biaya pengoperasian semakin tinggi (Muurine, 2000). Pelarut yang digunakan pada metode organosolv mempunyai tingkat volatilitas yang tinggi sehingga banyak pelarut yang menguap dan hilang pada proses fraksionasi.

Fraksionasi biomassa lignoselulosa yang ekonomis tidak bisa lepas dari tinjauan neraca massa komposisinya. Selain itu, biaya kebutuhan energi dapat terbantu dengan adanya daur ulang untuk memperoleh kembali pelarut yang digunakan untuk pemisahan tersebut (Kautto et al., 2013). Maka dari itu, penelitian ini dilakukan untuk mengetahui kondisi proses fraksionasi yang paling baik dan menguntungkan, yang dapat ditinjau melalui neraca massa, sehingga dapat diketahui berapa massa yang hilang dalam keseluruhan proses tersebut.

\section{Bahan dan Metode}

Bahan baku TKKS yang digunakan pada penelitian ini berasal dari daerah Sumatera. Proses perlakuan TKKS dilakukan dengan terlebih dahulu dicuci menggunakan air mengalir beberapa kali. Selanjutnya TKKS dikeringkan di bawah sinar matahari, lalu dikeringkan lebih lanjut dengan menggunakan oven blower dengan 
temperatur $60^{\circ} \mathrm{C}$ selama 24 jam. Kemudian TKKS tersebut digiling menggunakan disc mill dan disaring dengan ayakan tyler 60 mesh. Penelitian ini juga menggunakan bahan-bahan pembantu berupa, etanol teknis dengan kadar 96\%, larutan pekat $\mathrm{NH}_{4} \mathrm{OH}$ kadar 25\% (Merck), pellet $\mathrm{NaOH}$ teknis (Merck), larutan pekat $\mathrm{H}_{2} \mathrm{SO}_{4}$ kadar 95-97\% (Merck), dan air tanpa mineral.

\section{Fraksionasi Organosolv}

Sampel TKKS ditimbang sesuai variasi yang sudah dirancang, dan ditambahkan larutan yang dibutuhkan (pelarut etanol dan katalis $\mathrm{NH}_{4} \mathrm{OH}$ ). Penelitian ini menggunakan reaktor organosolv yang memiliki volume $100 \mathrm{~mL}$. Proses organosolv ini dilakukan dengan menggunakan sampel TKKS yang lolos oleh ayakan berukuran 60 mesh, larutan etanol 96\% berat volume, katalis $\mathrm{NH}_{4} \mathrm{OH} 1 \mathrm{M}$, dengan rasio fraksi berat, rasio etanol:air, temperatur, konsentrasi katalis dan waktu sesuai variasi yang telah dirancang.

\section{Variasi Percobaan Fraksionasi Organosolv}

Penelitian ini memvariasikan lima faktor operasi, yaitu:

1. Rasio fraksi berat $=10 \% ; 20 \%$

2. Rasio etanol:air $=1: 2 ; 1: 1$

3. Temperatur $=120^{\circ} \mathrm{C} ; 160^{\circ} \mathrm{C}$

4. Konsentrasi katalis $=5 \% ; 15 \%$

5. Waktu $=60 ; 120$ menit

Variasi percobaan yang dilakukan dirancang menggunakan Metode Placket-Burman
(Rushing et al., 2013) dengan bantuan program Minitab Pro 16.1.0.0, sehingga didapatkan 12 rancangan percobaan yang disajikan pada Tabel 1. Rancangan percobaan ini ditujukan untuk mengetahui pengaruh setiap variabel pada perolehan komposisi lignoselulosa TKKS.

\section{Hidrolisis Enzimatik}

Setelah TKKS diberikan perlakuan awal berupa fraksionasi organosolv sesuai rancangan percobaan, selanjutnya TKKS tersebut dihidrolisis secara enzimatik. Hidrolisis enzimatik ini digunakan sebagai tolok ukur potensi selulosa hasil fraksionasi untuk dikonversi menjadi bahan bakar berupa etanol. Metode hidrolisis enzimatik yang digunakan mengacu pada NREL (National Renewable Energy Laboratory) dengan nomor NREL/TP-510-42629 dengan ketentuan sebagai berikut: buffer Natrium Sitrat 0,05 M (pH 4,8), temperatur $50^{\circ} \mathrm{C}$, waktu 72 jam, dan konsentrasi biomassa 3\% (w/v). Hasil hidrolisis dianalisis menggunakan HPLC yang kemudian menjadi dasar perhitungan perolehan selulosa dan hemiselulosa.

\section{Penggunaan Kembali Pelarut}

Pelarut pada perlakuan awal organosolv etanol dapat digunakan kembali sebagai umpan. Penggunaan kembali pelarut tersebut dapat dilakukan setelah pemisahan lignin dari larutan organosolv (Muurine, 2000). Pemisahan lignin dapat dilakukan dengan cara presipitasi menggunakan asam pada $\mathrm{pH} 2$. Pada $\mathrm{pH} 2$ lignin

Tabel 1. Rancangan Percobaan Fraksionasi Organosolv Etanol Berkatalis $\mathrm{NH}_{4} \mathrm{OH}$

\begin{tabular}{cccccc}
\hline No. & Rasio fraksi berat & Etanol:air & Temperatur $\left({ }^{\circ} \mathrm{C}\right)$ & $\begin{array}{c}\text { Konsentrasi katalis } \\
\mathrm{NH}_{4} \mathrm{OH}\end{array}$ & $\begin{array}{c}\text { Waktu } \\
\text { (menit) }\end{array}$ \\
\hline 1. & $10 \%$ & $1: 1$ & 120 & $5 \%$ & 60 \\
2. & $10 \%$ & $1: 2$ & 160 & $15 \%$ & 120 \\
3. & $20 \%$ & $1: 1$ & 120 & $15 \%$ & 120 \\
4. & $10 \%$ & $1: 1$ & 160 & $15 \%$ & 60 \\
5. & $20 \%$ & $1: 2$ & 160 & $5 \%$ & 60 \\
6. & $10 \%$ & $1: 1$ & 160 & $5 \%$ & 120 \\
7. & $20 \%$ & $1: 1$ & 120 & $5 \%$ & 120 \\
8. & $20 \%$ & $1: 1$ & 120 & $15 \%$ & 60 \\
9. & $20 \%$ & $1: 2$ & 120 & $5 \%$ & 120 \\
10. & $10 \%$ & $1: 2$ & 120 & $15 \%$ & 120 \\
11. & $20 \%$ & $1: 2$ & 160 & $15 \%$ & 60 \\
12. & $10 \%$ & $1: 2$ & 120 & $5 \%$ & 60 \\
\hline
\end{tabular}


dapat mengendap maksimal (Garcia et al., 2009). Asam yang dapat digunakan untuk presipitasi lignin antara lain $\mathrm{H}_{2} \mathrm{SO}_{4}$ dan $\mathrm{HCl}$. Setelah penambahan asam, lignin akan mengendap, dan akan tersisa filtrat. Pada penelitian ini, pengendapan lignin dilakukan dengan menggunakan $\mathrm{H}_{2} \mathrm{SO}_{4} 20 \%$ hingga $\mathrm{pH} 2$.

Lignin diendapkan melalui rangkaian buchner dan pompa vakum, sehingga pelarut terpisah sebagai filtrat dan lignin dapat ditampung pada kertas saring. Lignin yang tertampung pada kertas saring dikeringkan dan ditimbang, sedangkan filtrat dianalisis menggunakan alat HPLC (High Performance Liquid Chromatography) untuk mengetahui kadar etanol yang tersisa. Larutan etanol yang tersisa kemudian dibasakan $(\mathrm{pH}>7)$, dengan menambahkan $\mathrm{NH}_{4} \mathrm{OH}$, dan digunakan kembali sebagai umpan pelarut pada fraksionasi organosolv.

\section{Analisis dan Karakterisasi Produk}

Analisis dilakukan dengan mengkarakterisasi komposisi lignoselulosa TKKS sebelum dan setelah perlakuan awal. Karakterisasi dilakukan dengan metode NREL/TP-51042618. Karakterisasi NREL dilakukan dengan menambahkan sampel TKKS ke dalam $\mathrm{H}_{2} \mathrm{SO}_{4}$ dan air tanpa mineral. Larutan tersebut kemudian disaring menggunakan cawan krus berpenyaring yang dirangkai dengan pompa vakum. Selanjutnya filtrat larutan tersebut diuji kadar selulosa, hemiselulosa dan lignin larut asamnya. sedangkan padatan bersama cawan krus dipanaskan dalam oven pada $105 \pm 3{ }^{\circ} \mathrm{C}$ selama 16 jam dan dibakar dalam tungku pembakaran pada $575 \pm 3{ }^{\circ} \mathrm{C}$ selama empat jam. Berat padatan pada cawan krus diukur sebagai lignin tak larut asam. Kadar selulosa, hemiselulosa dianalisis menggunakan alat HPLC (Waters, Breeze QS System, Amerika Serikat) yang dilengkapi dengan kolom BioRad Aminex HPX-87H. Sementara itu, kadar lignin larut asam dianalisis menggunakan spektrofotometer UV-Vis (Shimadzu, UV-1800, Jepang) pada panjang gelombang $205 \mathrm{~nm}$. Hasil analisis menggunakan spektrofotometer UVVis berupa absorbansi kemudian menjadi dasar perhitungan kadar lignin terlarut. Lignin yang tidak larut dianalisis dengan metode gravimetri, kemudian dijumlahkan dengan lignin terlarut, dan dikurangi dengan ekstraktif. Lignin sebelum dan setelah fraksionasi kemudian dibandingkan dan menghasilkan persentase yang disebut sebagai penghilangan lignin.

Hasil analisis HPLC berupa luas area larutan dikonversi menjadi konsentrasi gula pereduksi sebagai dasar perhitungan perolehan hemiselulosa dan selulosa. Perhitungan perolehan hemiselulosa adalah hemiselulosa setelah terpecah ikatannya oleh perlakuan awal dibandingkan dengan hemiselulosa sebelum perlakuan awal. Perhitungan perolehan selulosa adalah selulosa setelah terpecah ikatannya oleh perlakuan awal dibandingkan dengan selulosa sebelum perlakuan awal.

\section{Hasil dan Pembahasan}

Hasil karakterisasi TKKS sebelum perlakuan awal yaitu selulosa $21,06 \% \pm 2,7 \%$, hemiselulosa $8,39 \% \pm 2,33 \%$ dan lignin $26,11 \% \pm 0,34 \%$. Karakterisasi komponen lignoselulosa TKKS pada penelitian ini dilakukan 6 kali dengan pengulangan secara duplo. Hasil karakterisasi ini disajikan pada Tabel 2.

Data dari Tabel 2 menunjukkan bahwa komposisi selulosa dan hemiselulosa yang didapatkan pada penelitian ini lebih rendah dari literatur, sedangkan komposisi lignin dan ekstraktif lebih besar daripada literatur. Hal ini karena komposisi lignoselulosa TKKS sangat beragam, dipengaruhi oleh kondisi lahan, metode pemanenan, pengeringan dan penggilingan TKKS (Chiesa et al., 2014). Selain itu komposisi lignoselulosa TKKS juga dapat dipengaruhi oleh faktor penyimpanan. Penyimpanan dalam

Tabel 2. Hasil Karakterisasi Komposisi Lignoselulosa TKKS sebelum Perlakuan Awal

\begin{tabular}{lccc}
\hline Komponen Lignoselulosa & Penelitian ini & Chiesa et al. (2014) & Triwahyuni et al. (2015) \\
\hline Selulosa & $21,06 \% \pm 2,7 \%$ & $29,6 \%$ & $36,6 \%$ \\
Hemiselulosa & $8,39 \% \pm 2,33 \%$ & $18,8 \%$ & $25,0 \%$ \\
Lignin & $26,11 \% \pm 0,34 \%$ & $22,9 \%$ & $26,5 \%$ \\
Ekstraktif dan abu & $44,43 \% \pm 4,98 \%$ & $28,7 \%$ & $11,9 \%$ \\
\hline
\end{tabular}




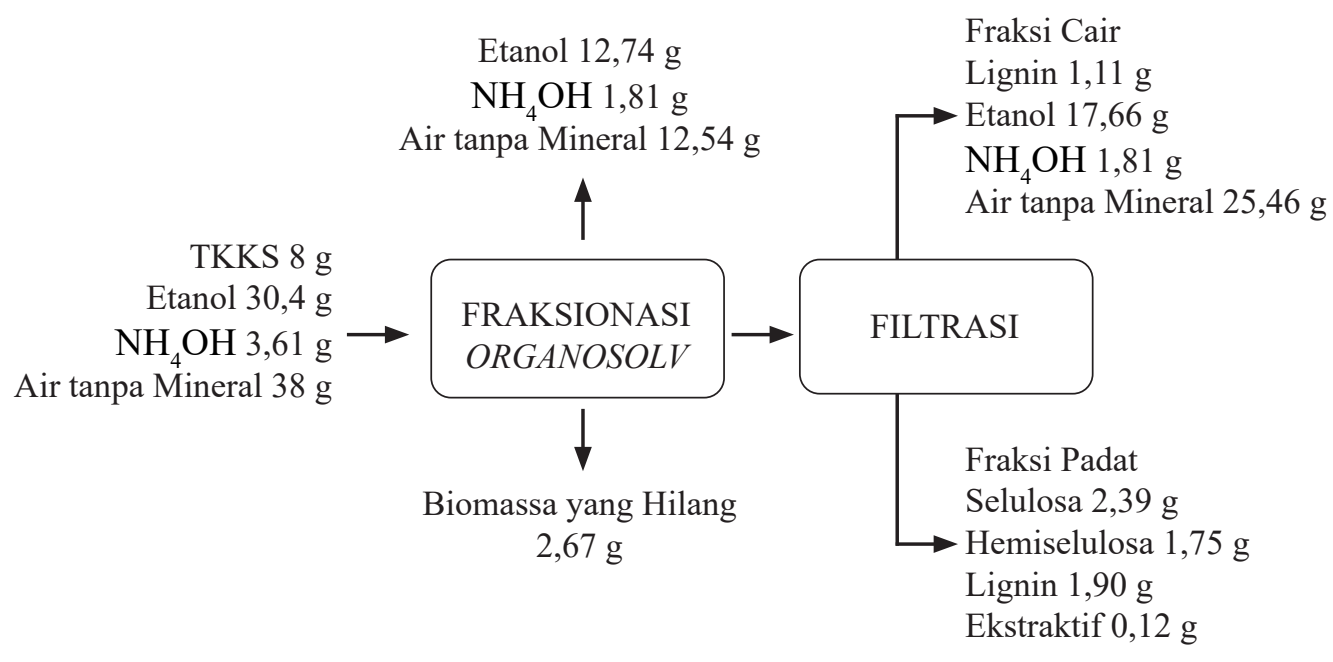

Gambar 1. Neraca Massa Fraksionasi Organosolv Lignoselulosa TKKS

waktu lama dengan sirkulasi udara yang kurang baik dapat menurunkan kualitas TKKS. Dalam penelitian ini bahan TKKS telah di simpan selama 3 bulan.

Selama berlangsungnya proses fraksionasi organosolv dengan pelarut organik dan penambahan pelarut asam, akan terjadi reaksi berupa pemotongan lignin dan lalu terlarut dalam pelarut organik, dan jalur utama pemecahan lignin adalah pembelahan yang dikatalisasi oleh asam dari hubungan $\beta-\mathrm{O}-4$ dan ikatan ester. Karbohidrat mengalami reaksi hidrolisis dan kemudian larut dalam larutan organosolv sebagai gula oligomer dan gula monomer, dan kemungkinan bereaksi lebih jauh terhadap produk degradasi gula (Kautto et al., 2013).

Parameter keberhasillan fraksionasi pada penelitian ini diukur dari nilai penghilangan lignin. Penghilangan lignin adalah persentase hilangnya lignin dari padatan biomassa lignoselulosa akibat terdegradasi oleh proses perlakuan awal. Persentase penghilangan lignin akan meningkat setelah perlakuan awal.

Hasil penelitian disajikan pada Tabel 3, dengan rancangan 12 percobaan didapatkan dari program Minitab Pro 16.1.0.0.2. Penghilangan lignin paling besar diperoleh pada percobaan ke-6 yaitu 64,23\%. Kondisi proses pada tempuhan tersebut adalah rasio fraksi berat $10 \%$, temperatur $160^{\circ} \mathrm{C}$, perbandingan etanol:air sebanyak $1: 1$, konsentrasi katalis 5\%, selama 120 menit. Selain itu, selulosa enzimatik yang tinggi didapatkan pada temperatur $160{ }^{\circ} \mathrm{C}$ selama 120 menit, kondisi operasi tersebut dijadikan sebagai batasan agar mendapatkan perolehan selulosa dan hemiselulosa yang tinggi, namun tidak terjadi depolimerisasi dari komponen lignoselulosa.

\section{Penggunaan Kembali Larutan Organosolv}

Berdasarkan hasil eksperimen, diperoleh bahwa kondisi operasi fraksionasi organosolv yang disarankan pada penelitian ini adalah biomass loading $10 \%$, temperatur $160^{\circ} \mathrm{C}$, perbandingan etanol:air 1:1, konsentrasi katalis 5\%, selama 120 menit. Kondisi operasi tersebut menghasilkan perolehan selulosa 98,07\%, perolehan hemiselulosa $98,71 \%$ dan penghilangan

Tabel 3. Hasil Percobaan Organosolv Etanol Berkatalis $\mathrm{NH}_{4} \mathrm{OH}$

\begin{tabular}{clc}
\hline No & $\begin{array}{l}\text { Penghilangan } \\
\text { Lignin }\end{array}$ & $\begin{array}{c}\text { Selulosa } \\
\text { Enzimatik }\end{array}$ \\
\hline 1. & $57,77 \%$ & $23,72 \%$ \\
2. & $63,95 \%$ & $61,42 \%$ \\
3. & $35,58 \%$ & $18,84 \%$ \\
4. & $43,39 \%$ & $70,12 \%$ \\
5. & $58,42 \%$ & $50,44 \%$ \\
6. & $64,23 \%$ & $33,43 \%$ \\
7. & $47,97 \%$ & $37,62 \%$ \\
8. & $33,13 \%$ & $3,14 \%$ \\
9. & $51,76 \%$ & $0,08 \%$ \\
10. & $49,39 \%$ & $25,86 \%$ \\
11. & $44,00 \%$ & $0,99 \%$ \\
12. & $51,45 \%$ & $26,64 \%$ \\
\hline
\end{tabular}




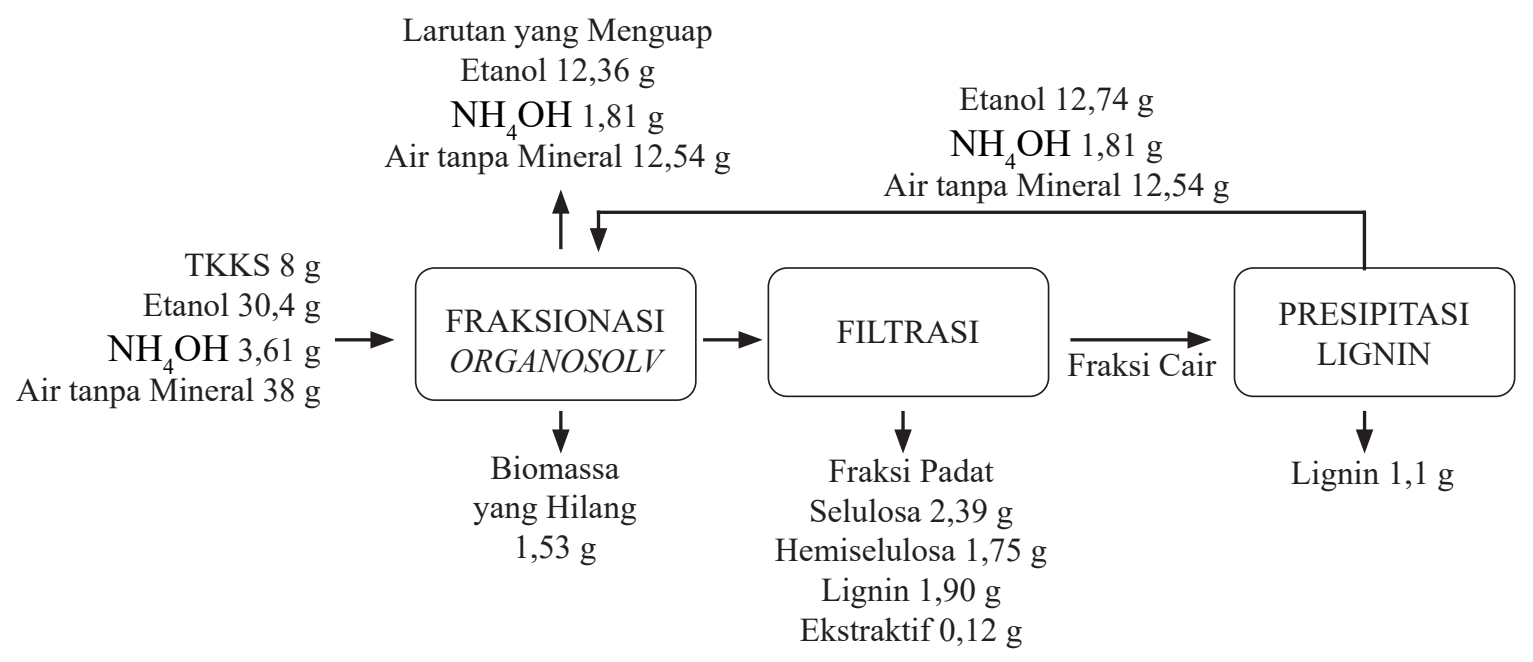

Gambar 2. Skema Neraca Massa Proses Fraksionasi Organosolv Lignoselulosa TKKS

lignin $60,28 \%$. Hasil fraksi cair dari eksperimen ini masih mengandung lignin terlarut, etanol, air dan katalis $\left(\mathrm{NH}_{4} \mathrm{OH}\right)$, hal ini dapat diamati dari neraca massa yang ditampilkan di Gambar 1.

Dari neraca massa tersebut, dapat dilihat bahwa masih ada sisa etanol setelah perlakuan awal yang dapat digunakan kembali sebagai umpan. Sisa etanol pada fraksi cair tersebut adalah $17,66 \mathrm{~g}$. Sisa etanol tersebut masih cukup tinggi jika dibandingkan dengan etanol umpan, yaitu 30,4 g. Fraksi cair ini dapat digunakan sebagai umpan untuk meminimalkan biaya. Berdasarkan hal tersebut, kita dapat merancang sebuah proses yang lebih ekonomis dibandingkan jika hanya membuang fraksi cair tersebut.

\section{Proses Fraksionasi Lignoselulosa TKKS}

Proses dimulai dengan memasukkan TKKS ke dalam reaktor organosolv bersama dengan etanol dan $\mathrm{NH}_{4} \mathrm{OH}$. Setelah perlakuan awal organosolv selesai, dilakukan penyaringan menggunakan kain saring sehingga terpisah antara fraksi padat dan cair. Fraksi padat dikarakterisasi menggunakan metode NREL untuk didapatkan komposisi selulosa, hemiselulosa dan lignin. Fraksi cair diendapkan mengunakan asam sulfat $\left(\mathrm{H}_{2} \mathrm{SO}_{4}\right)$ untuk memisahkan pelarut dari lignin, sehingga pelarut dapat digunakan kembali sebagai umpan reaktor.

Penggunaan kembali larutan organosolv pada proses fraksionasi organosolv ini dilakukan setelah lignin dipisahkan melalui presipitasi dengan asam. Setelah lignin terpisah, fraksi cair hasil fraksionasi organosolv dinetralkan sampai $\mathrm{pH} 7$ terlebih dahulu untuk selanjutnya fraksi cair tersebut digunakan sebagai umpan pelarut pada fraksionasi organosolv dengan penambahan katalis. Hasil percobaan penggunaan kembali fraksi cair hasil fraksionasi organosolv sebagai umpan pada penelitian ini disajikan pada Tabel 4.

Data pada Tabel 4 menunjukkan bahwa pada percobaan penggunaan kembali larutan organosolv, mengindikasikan penurunan hasil perolehan selulosa, perolehan hemiselulosa dan penghilangan lignin, namun penurunan tersebut tidak terlalu signifikan. Penurunan paling besar ditunjukkan oleh perolehan hemiselulosa, hal ini disebabkan oleh peningkatan konsentrasi basa pada penggunaan ke-2 untuk mengubah sifat larutan menjadi basa. Konsentrasi basa yang tinggi dapat mendegradasi hemiselulosa menjadi oligomer gula penyusunnya (Yoo, 2012). Berdasarkan hasil tersebut, maka penggunaan kembali larutan organosolv dapat menjadi salah satu opsi untuk menurunkan biaya fraksionasi organosolv.

Tabel 4. Pengaruh Penggunaan Pelarut terhadap Parameter Percobaan

\begin{tabular}{lcc}
\hline Parameter & $\begin{array}{c}\text { Penggunaan } \\
1 \mathrm{x}\end{array}$ & $\begin{array}{c}\text { Penggunaan } \\
2 \mathrm{x}\end{array}$ \\
\hline $\begin{array}{l}\text { Perolehan } \\
\text { Selulosa }\end{array}$ & $98,07 \%$ & $98,03 \%$ \\
$\begin{array}{l}\text { Perolehan } \\
\text { hemiselulosa } \\
\text { Penghilangan } \\
\text { lignin }\end{array}$ & $98,71 \%$ & $65,61 \%$ \\
\hline
\end{tabular}




\section{Perhitungan Neraca Massa pada Proses Fraksionasi Organosolv Berkatalis $\mathrm{NH}_{4} \mathrm{OH}$}

Sebuah proses tidak dapat dipisahkan dari perhitungan neraca massa untuk meninjau berapa banyak kehilangan yang terjadi. Perhitungan neraca massa ini juga menjadi pendekatan untuk meninjau tingkat kekonomian sebuah proses, sehingga dapat menjadi gambaran pengaplikasian penggunaan kembali fraksi cair organosolv sebagai umpan. Neraca massa proses fraksionasi organosolv disajikan pada Gambar 2. Neraca massa pada Gambar 2 tersebut dihitung berdasarkan hasil karakterisasi komponen selulosa, hemiselulosa dan lignin dari lignoselulosa TKKS sebelum dan setelah fraksionasi organosolv, berat lignin yang diperoleh setelah presipitasi, dan konsentrasi etanol sebelum dan setelah fraksionasi organosolv. Selain itu, konsentrasi $\mathrm{NH}_{4} \mathrm{OH}$ didasarkan pada penelitian Fulton (1950) yang menyatakan bahwa $\mathrm{NH}_{4} \mathrm{OH}$ yang dapat didaur ulang adalah setengah dari umpannya. Gambar 2 menunjukkan bahwa proses fraksionasi organosolv berkatalis $\mathrm{NH}_{4} \mathrm{OH}$ dengan penggunaan kembali fraksi cair sebagai umpan dapat diaplikasikan dan juga bersifat ekonomis. Neraca massa tersebut menunjukkan bahwa etanol yang dapat digunakan kembali sebagai umpan masih cukup tinggi, yaitu 59,34\% dari umpan etanol. Selain itu, kehilangan padatan TKKS hanya $1,525 \mathrm{~g}$, atau sekitar $19,06 \%$ dari umpan TKKS.

\section{Kesimpulan}

Hasil penelitian menunjukkan bahwa fraksionasi metode organosolv etanol berkatalis $\mathrm{NH}_{4} \mathrm{OH}$ dengan penggunaan kembali pelarut dapat dilakukan dengan baik pada kondisi operasi dengan biomassa loading $10 \%$, perbandingan etanol:air sebanyak $1: 1$, temperatur $160^{\circ} \mathrm{C}$, dan konsentrasi katalis 5\% $\mathrm{NH}_{4} \mathrm{OH}$, selama 120 menit. Larutan organosolv dapat digunakan kembali sebagai umpan pelarut setelah lignin dipisahkan melalui presipitasi lignin dengan penambahan $\mathrm{H}_{2} \mathrm{SO}_{4}$ pada $\mathrm{pH}$ 2. Proses fraksionasi organosolv dalam penelitian ini dapat menghasilkan penghilangan lignin yang cukup tinggi, dapat memperkecil kebutuhan pelarut dan memiliki kehilangan massa yang sedikit, sehingga proses ini bersifat ekonomis dan layak untuk dikembangkan. Lebih lanjut, proses fraksionasi ini masih perlu dikembangkan, terutama pada pemisahan lignin pada fraksi cair larutan organosolv.

\section{Daftar Pustaka}

Akgul,M., and Kirci,H.,(2009), 'AnEnvironmentally Friendly Organosolv (Ethanol-Water) Pulping of Poplar Wood', Journal Environmental Biology, 30, pp. 735-740.

Chiesa, S., and Gnansounou, E., (2014), 'Use of empty fruit bunches from the oil palm for bioethanol production: A thorough comparison between dilute acid and dilute alkali pretreatment', Bioresource Technology, 159, pp. 355-364.

Fuadi, A. M., and Pranoto, H., (2016), 'Pemanfaatan Limbah Tandan Kosong Kelapa Sawit Sebagai Bahan Baku Pembuatan Glukosa', Chemica, 3, pp. 23558776.

Garcia, A., Toledano, A., Serrano, L., Egues, I., Gonzalez, M., Marin, F., and Labidi, J., (2009), 'Characterization of lignins obtained by selective precipitation'. Separation and Purification Technology, 68(2), pp. 193-198.

Harmsen, P. F. H., Huijgen, W. J. J., Lopez, L. M. Bermudez, and Bakker, R. R. C., (2010), 'Literature Review of Physical and Chemical Pretreatment Processes for Lignocellulosic Biomass', Energy Research Centre of The Netherlands, pp. 30-32.

Kautto, J., Realff, M. J., and Ragauskas, A. J., (2013), 'Design and simulation of an organosolv process for bioethanol production', Biomass Conversion and Biorefenery, pp. 199-212.

Lopes, A. M. D, Joao, K. G., Morais, A. R., Bogel-Lukasik, E., and Bogel-Lukasik, R., (2013), 'Ionic Liquids as A Tool for Lignocellulosic Biomass Fractionation', Sustainable Chemical Processes, pp.14-15.

Mesa, L., Gonzalez, E., Cara, C., Gonzalez, M., Castro, E., and Mussatto, S.I., (2011), 'The Effect of Organosolv Pretreatment Variables On Enzymatic Hydrolysis of Sugarcane Bagasse', Chemical Engineering Journal, 168, pp. 1157-1162.

Muurine, E., (2000), 'Organosolv Pulping: A Review and Distillation Study Related to Peroxyacid Pulping', disertasi, University of Oulu, Linnanmaa, Finland.

North, Peter H., (2014), 'Method and System for Fractionation of Lignocellulosic Biomass', US Patent 8,657,960, pp. 14.

Park, J. K., and Phillips, J. A., (1988), 'Ammonia Catalyzed Organosolv Delignification of Poplar', Chemical Engineering Communications, 65, pp.187-205. 
Phanthong, P., Reubroycharoen, P., Hao, X., Xu, G., Abudula, A., Guan, G., (2018), 'Nanocellulose: Extraction and application', Carbon Resources Conversion, 1, pp. 32-43.

Rahmanulloh, A., (2020), 'Indonesia Oilseeds and Product Annual 2020', USDA Foreign Agricultural Service, 6, pp. 5.

Rushing H., A. Karl, and J. Wisnowski. (2013). Design and Analysis of Experiments by Douglas Montgomery. $1^{\text {st }}$ edn. Cary: SAS Institute.

Triwahyuni, E., Muryanto, Sudiyani, Y., and Abimanyu, H. (2015), 'The effect of substrate loading on simultaneous saccharification and fermentation process for bioethanol production from oil palm empty fruit bunches', Energy Procedia, 68, pp.138-146.
Wardani, A. P. K., and Widiawati, D., (2014), 'Pemanfaatan Tandan Kosong Kelapa Sawit Sebagai Material Tekstil Dengan Pewarna Alam Untuk Produk Kriya', Jurnal Tingkat Sarjana bidang Senirupa dan Desain, pp. $1-10$.

Wildschut, J., Smith, A. T., Reith, J. H., and Huijgen, W.J J., (2013), 'Ethanol-based organosolv fractionation of wheat straw for the production of lignin and enzymatically digestible cellulose', Bioresource Technology, 135, pp. 58-66.

Yoo, C. G., (2012), 'Pretreatment and fractionation of lignocellulosic biomass for production of biofuel and value-added products', disertasi, Iowa State University, Iowa. 